\title{
Galur Day Old Chicken Berpengaruh pada Perbandingan Rasio Heterofil: Limfosit saat Mengalami Transportasi dari Yogyakarta ke Makassar
}

\section{Day Old Chicken Strain Influence on the Ratio of Heterophil: Lymphocytes when Experiencing Transportation from Yogyakarta to Makassar}

\section{Rizka Indriani ${ }^{1) *}$, Pudji Astuti ${ }^{2}$, Amir Husni3 ${ }^{3)}$, Claude Mona Airin ${ }^{2}{ }^{*}$}

1) Program Studi Magister Sains Veteriner, Fakultas Kedokteran Hewan, Universitas Gadjah Mada, Yogyakarta

2) Departemen Fisiologi, Fakultas Kedokteran Hewan, Universitas Gadjah Mada, Yogyakarta

3) Departemen Perikanan, Fakultas Pertanian, Universitas Gadjah Mada, Yogyakarta

\section{Article history \\ Received: Jun 18, 2020; \\ Accepted: Mar 16, 2020 \\ * Corresponding author: \\ E-mail: \\ rizkaindriani@mail.ugm.ac. \\ id; monaairin@ugm.ac.id \\ DOI: \\ $\underline{10.46549 / j i p v e t . v 11 i 2 . ~} 129$

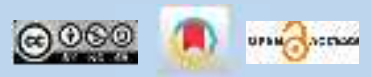

\begin{abstract}
Day Old Chicken (DOC) is a living commodity that is widely distributed between islands throughout Indonesia. Transport trip within two to 24 hours, depending on the distance of the enclosure to be addressed. During the DOC journey, a variety of stresses result in stress and also end in death. Strain DOC has different endurance. Physiological stress parameters in poultry by calculating the ratio of Heterophil:Lymphocytes (H:L). This study aims to determine the difference in stress between DOC strain Cobb and Java Super passed through. Research carried out using DOC strain Cobb as many as 100 chicken/box and Java Super 100 chicken/box. The transportation process from Yogyakarta airport (loading) to Makassar airport (landing). Furthermore, DOC was taken four animals randomly before and after it was passed for blood smear preparations. Blood smear preparations with Giemza staining to calculate the H:L ratio. Analysis of H:L ratio data as a comparison of body resistance to stress between DOC strain Cobb and Java Super using Two Way Anova with a 95\% confidence level. The results showed that there was no interaction $(\mathrm{P}>0.05)$ between location (loading-landing) and DOC strain different from H:L ratio. The difference in the DOC strain affects the H:L ratio $(\mathrm{P}<0.05)$ with the average value of the H:L ratio of DOC strain Java Super higher than the Cobb. The conclusion is that DOC was transported by airplane showed a difference in the $\mathrm{H}: \mathrm{L}$ ratio and there were no deaths.
\end{abstract}

Keywords: Day-Old Chicken; Rasio heterophil:lymphocytes; Stress; Transportation

\section{Abstrak}

Day Old Chicken (DOC) merupakan komoditas hidup yang banyak dilalulintaskan antar pulau di seluruh Indonesia. Perjalanan pengangkutan dalam waktu dua sampai 24 jam, tergantung jarak kandang yang akan dituju. Rasio Heterofil:Limfosit $(\mathrm{H}: \mathrm{L})$ dapat digunakan sebagai parameter awal adanya stress transportasi. Penelitian ini bertujuan untuk mengetahui rasio $\mathrm{H}: \mathrm{L}$ serta tingkat kematian DOC galur Cobb dan galur Jawa Super yang ditransportasikan dari Yogyakarta ke Makassar. Penelitian menggunakan DOC galur Cobb 100 ekor/boks dan galur Jawa Super 100 ekor/boks. Proses transportasi dari bandara Yogyakarta (loading) menuju bandara Makassar (landing). Day Old Chicken diambil empat ekor secara acak sebelum dan sesudah ditransportasikan. Darah keempat $D O C$ dibuat preparat apus darah untuk perhitungan rasio $\mathrm{H}: \mathrm{L}$. Analisis data rasio H:L sebagai perbandingan ketahanan tubuh terhadap stres antara DOC galur Cobb dan galur Jawa Super menggunakan Two Way Anova. Hasil 
penelitian menunjukkan bahwa tidak ada interaksi $(\mathrm{P}>0,05)$ antara lokasi (loading-landing) dan galur DOC berbeda terhadap rasio H:L. Perbedaan galur DOC mempengaruhi rasio H:L $(\mathrm{P}<0,05)$ dengan nilai rata-rata rasio $\mathrm{H}: \mathrm{L}$ DOC galur Super Jawa lebih tinggi dibandingkan galur Cobb. Kesimpulan bahwa DOC yang mengalami transportasi menggunakan pesawat terbang menunjukkan perbedaan rasio H:L dan tidak ada kematian.

Kata Kunci: Day Old Chicken; Rasio heterofil:limfosit; Stres; Transportasi.

\section{PENDAHULUAN}

Day Old Chicken merupakan komoditas hidup yang banyak dilalulintaskan dari pulau Jawa ke pulau lain di seluruh Indonesia, hal dikarenakan produsen bibit ayam terbesar berada di pulau Jawa yang tersebar di Propinsi Jawa Barat, Jawa Tengah dan Jawa Timur. Salah satu wilayah yang menjadi pusat lalu lintas DOC adalah Makassar di Sulawesi Selatan. Data dari Balai Besar Karantina Pertanian Makassar menunjukkan bulan Januari sampai dengan Juli 2019 jumlah DOC yang masuk ke wilayah Makassar 3.822.915 ekor. Day Old Chicken yang keluar dari Makassar menuju beberapa wilayah di Indonesia bagian Timur sejumlah 3.732 .300 ekor. Adapun tingkat kematian DOC galur tertentu mencapai $80 \%$. Proses transportasi DOC harus dalam waktu yang singkat sehingga pengguna jasa DOC memilih pesawat terbang sebagai alat angkut antar wilayah.

Day Old Chicken mengalami proses yang panjang mulai persiapan pengemasan kedalam kardus/box DOC, waktu perjalanan satu sampai tiga jam selama proses pengangkutan, perjalanan pengangkutan menuju kandang dalam waktu dua sampai 24 jam. Penurunan kualitas DOC dapat terjadi akibat proses transportasi, beberapa cekaman yang dialami oleh DOC selama perjalanan di antaranya dehidrasi, stres, guncangan dan perubahan suhu sehingga dapat menyebabkan DOC lemas, bahkan berakhir dengan kematian. Stres merupakan salah satu akibat yang ditimbulkan oleh cekaman selama proses perjalanan dari hatchery menuju kandang.

Beragam galur pada DOC memiliki ketahanan berbeda dalam menghadapi stres. Persilangan jenis ayam berbeda diharapkan menghasilkan galur yang memiliki genotipe yang tahan terhadap stres tanpa menghilangkan kualitas dan kuantitas karakteristik ayam tersebut. Seperti DOC Galur Cobb memiliki karakteristik pengembangan genetik pada pembentukan daging dibagian dada, mudah beradaptasi dengan lingkungan tropis (heat stress) (Pratiwi et al., 2016). Galur Jawa Super merupakan kawin silang antara ayam buras jantan dengan ayam layer petelur ras. Galur tersebut untuk memenuhi kebutuhan pasar masyarakat Indonesia yang menyukai ayam buras dibandingkan ayam ras karen daging kenyal, memiliki kandungan protein tinggi serta kadar lemak rendah (Triyantini et al., 1997).

Ciri-ciri hematik yang dipengaruhi oleh faktor eksperimental adalah heterofil $(\mathrm{H})$ dan limfosit (L). Diketahui secara luas bahwa stres meningkatkan $\mathrm{H}$ dan menurunkan L; karenanya, rasio $\mathrm{H}: \mathrm{L}$ adalah indeks respons yang baik terhadap stressor (Yue et al., 2010). Rasio H:L merupakan indikator stres yang paling mudah diketahui secara dini. Penelitian ini bertujuan untuk mengetahui ketahanan tubuh dua galur DOC berbeda yang mengalami transportasi menggunakan pesawat terbang.

\section{MATERI DAN METODE}

Penelitian ini menggunakan DOC galur Cobb dan Jawa Super masing-masing empat ekor dari UD. Widya Anggoroganik Penguasa Pulau, Yogyakarta. Day Old Chicken dilalulintaskan menggunakan pesawat terbang dari Yogyakarta menuju Makassar. Pengambilan sampel di dua titik pemberhentian yaitu: Kantor PT. Trans Sarana Jaya (Loading) kargo Bandara Internasional Adisujipto Yogyakarta dan Kantor Pelayanan Karantina Bandara Internasional Sultan 
Hasanuddin Balai Besar Karantina Pertanian Makassar (Landing).

Pengambilan sampel darah DOC dilakukan di bagian bawah otak sebelah belakang. Satu tetes darah diletakkan pada gelas onjek kemudian diapus/digesekkan dengan ujung gelas objek yang lain. Preparat apus darah untuk menghitung rasio $\mathrm{H}: \mathrm{L}$. Preparat apus darah dari empat ekor DOC galur Cobb dan empat ekor galur Jawa Super yang diambil secara acak sebelum dilalintaskan. Selanjutnya empat ekor DOC yang baru dan sudah ditandai dari masingmasing dimasukkan ke dalam kardus agar jumlah DOC tetap dan sesuai kondisi di lapangan ketika dilalulintaskan. Preparat apus darah kedua diambil setelah DOC sampai tujuan dengan jumlah empat ekor pada masing-masing galur. Analisa data hasil rasio H:L antara DOC galur Cobb dan galur Jawa Super menggunakan SPSS dengan uji statistika Two Way Anova. Seluruh perlakuan pada hewan telah pendapat persetujuan komisi etik Fakultas Kedokteran Hewan Universitas Gadjah Mada dengan nomer 0130/ECFKH/Int./2019.

\section{HASIL DAN PEMBAHASAN}

DOC galur Cobb dan galur Jawa Super tidak ada kematian dengan angka mortalitas 0 $\%$ sesuai Tabel 1. Rerata rasio H:L DOC galur Cobb dan galur Jawa Super yang mengalami transportasi menggunakan pesawat terbang disajikan pada Tabel 1. Berdasarkan Tabel 1, nilai rerata rasio H:L DOC galur Jawa Super lebih tinggi 1,80 $\pm 0,29$ dibandingkan DOC galur Cobb 0,68 $\pm 0,13$ di lokasi Loading maupun Landing dengan DOC galur Jawa Super 1,73 $\pm 0,42$ lebih tinggi dibandingkan DOC galur Cobb 0,60 $\pm 0,08$. Perbedaan galur DOC mempengaruhi rasio $\mathrm{H}: \mathrm{L}$ secara signifikan $(\mathrm{P}<0,05)$. Hasil ini menunjukkan bahwa tingkat stres pada DOC galur Cobb lebih rendah dibandingkan DOC galur Jawa Super baik pada saat loading maupun landing.

Tabel 1. Mortalitas dan rerata rasio heterofil:limfosit DOC yang mengalami transportasi menggunakan pesawat

\begin{tabular}{|c|c|c|c|c|}
\hline \multirow{2}{*}{ Parameter } & \multicolumn{2}{|c|}{ DOC galur Cobb } & \multicolumn{2}{|c|}{ DOC galur Jawa Super } \\
\hline & Loading & Landing & Loading & Landing \\
\hline Mortalitas \% & 0,0 & 0,0 & 0,0 & 0,0 \\
\hline RatioH/L & $0,68 \pm 0,13^{\mathrm{a}}$ & $0,60 \pm 0,08^{\mathrm{b}}$ & $1,80 \pm 0,29^{c}$ & $1,73 \pm 0,42^{\mathrm{d}}$ \\
\hline
\end{tabular}

Ayam bukan ras atau ayam kampung mempunyai kemampuan adaptasi dengan lingkungan tropik cukup baik. Dalam perkembangannya, ayam kampung berkembang menjadi berbagai macam galur dengan fenotipe dan genotipe yang beragam (Tamzil et al., 2013). Penelitian dilakukan Rahayu et al. (2010) menunjukkan secara genetik persilangan indukan ayam kampung dengan ayam pejantan bangkok dapat meningkatkan pertambahan berat badan ayam bangkok dan konsumsi ransum ayam kampung. Keberagaman ini berdampak pada kemampuan merespons pengaruh lingkungan termasuk suhu lingkungan tempat pemeliharaan. Individu yang memiliki keragaman kombinasi gen tinggi memiliki kemampuan beradaptasi dengan lingkungan lebih baik dibandingkan dengan individu yang komposisi gennya lebih seragam (Tamzil et al., 2013).

Menurut Campo et al. (2008) ada pengaruh genetik mempengaruhi kemampuan heterofil dan limfosit terhadap stressor. Pada penelitian yang dilakukan (Mancinelli et al. (2018) menunjukkan bahwa DOC galur Naked Neck memiliki kemampuan tumbuh lambat serta nilai $\mathrm{H}$ dan $\mathrm{L}$ yang lebih tinggi daripada DOC Ross 308 setelah ditransportasikan selama empat jam. Seleksi genetik unggas untuk tingkat pertumbuhan mungkin tidak sengaja disertai oleh resistensi yang lebih rendah terhadap penyakit atau berkurangnya respons imunologi dan perubahan sifat-sifat hematologis utama (Qureshi and Havenstein, 1994). 
Pada penelitian ini tingkat mortalitas DOC galur Cobb $0 \%$ dan galur Jawa Super $0 \%$. Menurut EFSA (2011) metabolisme dalam tubuh DOC berasal dari yolk sac dan bertahan selama 3 hari. Menurut Tanaka and Xin (1997) aliran sirkulasi kotak DOC bersifat pasif dan memadai selama berada di gudang sebelum penerbangan, lepas landas, selama terbang dan mendarat dengan cepat menghasilkan kondisi tekanan panas potensial bahkan ketika suhu eksternal cukup hangat.

Mitchell (2009) semakin banyak jumlah DOC yang dilalulintaskan melalui udara dengan jarak jauh menyebabkan kemampuan bertahan yang kurang optimal dan merupakan masalah signifikan terkait kesejahteraan hewan. Suhu kompartemen, level $\mathrm{CO}_{2}$, dan tingkat kelembaban tergantung pada suhu sekitar, jenis hewan, jumlah hewan yang akan diangkut, kemampuan paket pendingin udara pesawat, dan pengaturan Environmental Control System (ECS). Pengaturan suhu kompartemen yang diinginkan untuk hewan tidak serta merta menghasilkan suhu yang diatur dari dek penerbangan (Le, 2012). Xin and Rieger (1995) kondisi transportasi udara juga berkorelasi dengan kondisi termal di palka pesawat yang tidak terkontrol dengan baik pada penerbangan jarak jauh. Suhu tubuh hewan dapat menghasilkan suhu kompartemen yang lebih tinggi daripada yang ditetapkan dari dek penerbangan. Tingkat kematian mencapai $0 \%$ dapat disebabkan karena saat pengiriman DOC sudah mengikuti kaidah animal welfare yaitu meletakkan DOC sesuai jarak atau ruang kosong antara DOC 21-25 $\mathrm{cm}^{2}$. Hal ini menyebakan DOC mampu melakukan adaptasi suhu tubuh selama transportasi sehingga tidak mengganggu fisiologis tubuh.

Suhu dalam kardus DOC turun dengan cepat sebesar $7^{0} \mathrm{C}$ pada saat keberangkatan dan meningkat hingga $10^{\circ} \mathrm{C}$ saat mendarat. Tekanan suhu tinggi teramati selama pesawat sebelum lepas landas dan saat mendarat (Mitchell, 2009). Tingkat kelembaban dan $\mathrm{CO}_{2}$ di dalam kompartemen tidak dapat dikontrol oleh pengaturan ECS. Pasokan udara yang dikondisikan dari sirkulasi udara, yang terletak di langit-langit atau dinding samping (tergantung pada desain dan model pesawat), mengandung uap air dan $\mathrm{CO}_{2}$ sebelum tercampur dengan udara di dalam kompartemen. Kondisi pasokan udara yang dikombinasikan dengan suhu tubuh hewan, $\mathrm{CO}_{2}$, dan pembentukan kelembaban menentukan sifat-sifat udara kompartemen secara keseluruhan (Le, 2012).

Day Old Chicken tergolong unggas yang merupakan hewan homeothermic (berdarah panas) dengan ciri spesifik tidak memiliki kelenjar keringat serta hampir semua bagian tubuh tertutup bulu. Kondisi ini menyebabkan unggas dalam kondisi panas mengalami kesulitan membuang panas tubuh ke lingkungan dan unggas menunjukkan ciri-ciri gelisah, panting dengan frekuensi yang berbanding lurus dengan tingkat stres dan suhu rektal meningkat (Tamzil, 2014).

\section{KESIMPULAN}

Berdasarkan penelitian diatas dapat disimpulkan bahwa adanya perbedaan yang signifikan $(\mathrm{p}<0.05)$ rasio $\mathrm{H}: \mathrm{L}$ saat Loading maupun Landing pada DOC galur Cobb dan Jawa Super yang ditransportasikan menggunakan pesawat dengan tingkat kematian 0\% sehingga dapat dikatakan bahwa kedua galur tersebut mempunyai ketahanan tubuh yang berbeda untuk menanggulangi stres transportasi dan perhitungan rasio $\mathrm{H}: \mathrm{L}$ sebagai rekomendasi parameter awal stres transportasi.

\section{DAFTAR PUSTAKA}

Campo JL, Prieto MT and Davila SG. 2008. Effects of Housing System and Cold Stress on Heterophil-to-Lymphocyte Ratio, Fluctuating Asymmetry, and Tonic Immobility Duration of Chickens. Poultry Science, 87(April 2008), 621-626.

EFSA. 2011. Scientific Opinion Concerning the Welfare of Animals during Transport 1. EFSA Journal, 9(1255), 1-44.

Le L. 2012. Safe Transport of Live Animal Cargo. Aeromagazine, QTR 02, 16-25. https://www.boeing.com/commercial/aero magazine/articles/2012_q2/pdfs/AERO_2 012q2_article4.pdf

Mancinelli AC, Mugnai C, Castellini C, Mattioli S, Moscati L, Piottoli L, Amato MG, Doretti M, Bosco AD, Cordovani E, Abbate Y, Ranucci D, Cartoni A and Mugnai C. 2018. Effect of Transport 
Length and Genotype on Tonic Immobility, Blood Parameters and Carcass Contamination of Free-Range Reared Chickens. Italian Journal of Animal Science, O(0), 557-564.

Mitchell MA. 2009. Chick Transport and Welfare. Avian Biology Research, 2(1/2), 99-105.

Pratiwi MS, Pagala MA dan Aku SA. 2016. Produksi Karkas dan Lemak Abdominal Ayam Broiler Strain Cobb dan Strain Lohmann yang Diberi Pakan Berbeda. Journal of Tropical Animal Science and Technology, 1(1), 1-6.

Qureshi MA and Havenstein GB. 1994. A Comparison of the Immune Performance of a 1991 Commercial Broiler with a 1957 Randombred Strain When Fed "Typical” 1957 and 1991 Broiler Diets1. Poultry Science, 73(12), 1805-1812.

Rahayu BWI, Widodo AEP dan Sarunggalo R. 2010. Penampilan Pertumbuhan Ayam Persilangan Kampung dan Bangkok. Jurnal Ilmu Peternakan, 5(2), 77-81.

Tamzil MH. 2014. Stres Panas pada Unggas : Metabolisme, Akibat dan Upaya Penanggulangannya. Wartazoa, 24(2), 57-66.

Tamzil MH, Noor RR, Hardjosworo PS,
Manalu W dan Sumantri C. 2013. Keragaman Gen Heat Shock Protein 70 pada Ayam Kampung, Ayam Arab, dan Ayam Ras. Jurnal Veteriner, 14(3), 317326.

Tanaka A and Xin H. 1997. Effects of Structural and Stacking Configuration of Containers for Transporting Chicks in their Microenvironment. Transactions of the ASABE, 40(3), 777-782.

Triyantini, Abubakar, Bintang IAK dan Antawidjaja T. 1997. Studi komparatif preferensi, mutu dan gizi beberapa jenis daging unggas. Jurnal Ilmu Ternak Dan Veteriner, 2(3), 157-162.

Xin $\mathrm{H}$ and Rieger SR. 1995. Physical Conditions and Mortalities Associated with International Air Transport of Young Chicks Physical Conditions and Mortalities Associated with International Air. Journal Paper No. J-16201 of the Iowa Agriculture and Home Economics Experiment Station, 38(6), 1863-1867.

Yue HY, Zhang L, Wu SG, Xu L, Zhang, HJ and Qi GH. 2010. Effects of Transport Stress on Blood Metabolism, Glycolytic Potential, and Meat Quality in Meat-Type Yellow-Feathered Chickens. Poultry Science, 89(3), 413-419. 